\title{
Cranial computed tomography scan findings in acute head injury
}

Abstract
Background and objective: Head injury is a common injury seen in emergency
departments. Early diagnosis and treatment may ameliorate the morbidity and mortality
associated with intracranial injury. Computed tomography (CT) scan of the brain is
a reliable imaging modality for identification of intracranial lesions in patients with an acute
head injury. This study aimed to assess the cranial CT scan findings in patients with acute
head injury, find out the main indication for requesting CT scan imaging, detect main
etiologic factors and its distribution among different age groups.

Methods: This was a prospective cross-sectional study of cranial CT scan findings of 210 patients with acute head injury admitted to an emergency hospital in Hawler during three months. Numerical and graphical descriptors were used to summarize the data.

Results: The age of the studied patients ranged from 2 to 67 years with a mean \pm SD of $29.23 \pm 15.1$ with males dominating the sample $(78.6 \%)$. Road traffic accident was the main cause of injury (65.7\%). The most common indication for requesting a CT scan was an altered level of consciousness and vomiting. Intracranial CT scan findings related to head injury were seen in $82 \%$ of victims of which fractures $(50 \%)$ and intracranial hematomas $(45.2 \%)$ were the main findings followed by combined injuries(31.8) and soft tissue injuries $(31.6 \%)$.Incidental intracranial findings not related to trauma were seen in $6.2 \%$ of cases.

Conclusion: In patients with acute head injury, CT scan can be used as the initial imaging investigation as it can yield various types of head injuries and their consequences related to trauma.

Keywords: Rozhhalat Emergency Hospital; CT scan; Head injury; RTA.

\section{Introduction}

The most frequent lesion seen in trauma related-death is head trauma which is any injury that causes lesion or functional damage of the cranium, meninges, and brain. Victims with head trauma may have one or combination of injuries whether intra or extracranial. ${ }^{1}$ Half of head injury cases will experience un-favorable outcomes and it is an important cause of death and disability in young adults. ${ }^{2}$ Trauma secondary to road traffic accident (RTA) constitutes a major cause of head injury, leading to $70 \%$ of all deaths due to brain injury. Among the severely injured patients, the majority survives with severe morbidity, and minority continues to be in the vegetative state. Increasing ageis associated with poor outcome. ${ }^{3}$ Annually; thousands of victims are affected by head injury predominantly among young males probably due to increased activity among them. Common etiological factors of head injury include road traffic accidents, assaults, falls and stab wounds. ${ }^{4}$ According to $\mathrm{WHO}$, head injury will surpass many diseases as the major cause of death and disability by the year 2020. ${ }^{5}$ Nowadays computed tomography (CT) scan is established as the investigation of choice in patients with an acute head injury with a sensitivity and specificity approaching $100 \%$ for detecting surgically significant head injuries. ${ }^{6}$ The advantages of CT scan in the evaluation of patients with head injury include its * Department of Surgery, College of Medicine, Hawler Medical University, Erbil, Iraq. 
sensitivity for detecting a mass effect, ventricular size and configuration, bone injuries and acute hemorrhage. Widespread availability, fast scanning, and compatibility with medical devices are other well-known advantages of CT scan. ${ }^{7}$ This study aimed to assess the cranial CT scan findings in patients with acute head injury, find out the main indication for requesting CT scan imaging, and detect main etiologic factor and its distribution among different age groups

\section{Methods}

This prospective cross-sectional study was an analysis of prospectively recorded data and cranial CT scan findings of 210 patients with acute head injury (irrespective of their Glasgow Coma Score) who were admitted to radiology department of Rozhhalat Emergency Hospital in Hawler, Kurdistan region of Iraq, from June 2017 to December 2017.After approval from the Ethics Committee at the College of Medicine, Hawler Medical University and written approval from the Rozhhalat Emergency Hospital, the request forms and CT scan images of patients with acute head injury were checked. The inclusion criteria included the patients with a history of acute head injury, either head injury alone or in the setting of polytrauma. The exclusion criteria included follow up cases of previous head injury. Information is available on the request forms were documented including the demographic characteristics, type of injury (road traffic accidents, falls, and assault and aggression injuries), and the main indication(s) for CT scan. Noncontrast CT scan was performed as soon as possible after the patient's arrival in the radiology department. All scans were performed using TOSHIBA Aquilion CT scan machine, non-contrast sequential axial 10 $\mathrm{mm}$ thickness slices were obtained extending from the skull base to the vertex, the images were viewed in bone and brain windows with multiplanar reconstructions (MPR)in sagittal and coronal planes with special attention to the skull base, paranasal sinuses, and mastoid air cells. CT scan findings were analyzed and classified into normal and abnormal CT scan. Abnormal cranial CT findings were documented including scalp injuries (swelling, laceration, subcutaneous emphysema, foreign bodies, and avulsion), intra axial hemorrhage (intraparenchymal hemorrhage), extra-axial hemorrhage (subdural, epidural, and subarachnoid hemorrhage, intraventricular haemorrhage), brain swelling, midline shift, and skull fractures (type, location, association with intracranial hematoma. Data entry and analysis were carried out using the statistical package for the social sciences (version 18). Both descriptive and analytic approaches were performed. The descriptive approach included determining frequencies and percentages, while analytic approach includedcalculating the Chi-square association test and Fisher's exact test for the categorical variables. A $P$ value of $\leq 0.05$ was regarded as a statistically significant.

\section{Results}

Out of the total of 210 patients, 165 $(78.6 \%)$ were males and45 (21.4\%) were females. The mean $\pm S D$ age was $29.23 \pm 15.1$ (range 2 to 67 years). Most cases $(82 \%)$ showed abnormal CT scan findings (whether single or combined findings), and $18 \%$ of cases were normal (no findings related to trauma). The main cause of injury was RTA, fall, and assault injury $(65.7 \%, \quad 19.5 \%$, and $14.8 \%)$ respectively. Table 1 shows indications for a CT scan; most of the indications were a change of consciousness, vomiting, and change of consciousness +vomiting $(41.9 \%, 9.5 \%$, and $11.9 \%)$ respectively. Out of the total of 210 patients, 165 $(78.6 \%)$ were males and45 (21.4\%) were females. The mean $\pm S D$ age was $29.23 \pm 15.1$ (range 2 to 67 years). Most cases $(82 \%)$ showed abnormal CT scan findings (whether single or combined findings), and $18 \%$ of cases were normal 
(no findings related to trauma). The main cause of injury was RTA, fall, and assault injury $(65.7 \%, 19.5 \%$, and $14.8 \%)$ respectively. Table 1 shows indications for a CT scan; most of the indications were a change of consciousness, vomiting, and change of consciousness +vomiting $(41.9 \%, 9.5 \%$, and $11.9 \%)$ respectively.
The current study showed that nearly half $(48.6 \%)$ of cases had a linear fracture type, while combined fracture (linear+ depressed) constitutes only 1\% (Figure 1). The most common hematoma type was intracerebral (42.9\%) and epidural (25.6\%) (Figure 2).

Table 1: Indications of performing CT scan among the study sample.

\begin{tabular}{lcc}
\hline Indications & No. & $(\%)$ \\
\hline Change of consciousness & 88 & $(41.9)$ \\
Change of consciousness +vomiting & 25 & $(11.9)$ \\
Vomiting & 20 & $(9.5)$ \\
Convulsion & 16 & $(7.6)$ \\
Facial injury & 16 & $(7.6)$ \\
Shock & 11 & $(5.2)$ \\
Headache & 7 & $(3.3)$ \\
Vomiting +headache & 7 & $(3.3)$ \\
Nasal/ or discharge & 5 & $(2.4)$ \\
Cervical spine injury & 5 & $(2.4)$ \\
Change of consciousness+ headache & 3 & $(1.4)$ \\
Facial injury +nasal/or discharge & 2 & $(1.0)$ \\
Change of consciousness+ convulsion & 1 & $(0.5)$ \\
Headache+ vomiting & 1 & $(0.5)$ \\
Nasal/or oral discharge & 1 & $(0.5)$ \\
Change of consciousness +vomiting +convulsion & 1 & $(0.5)$ \\
Shock +cervical spine injury & 1 & $(0.5)$ \\
Total & 210 & $(100.0)$ \\
\hline
\end{tabular}

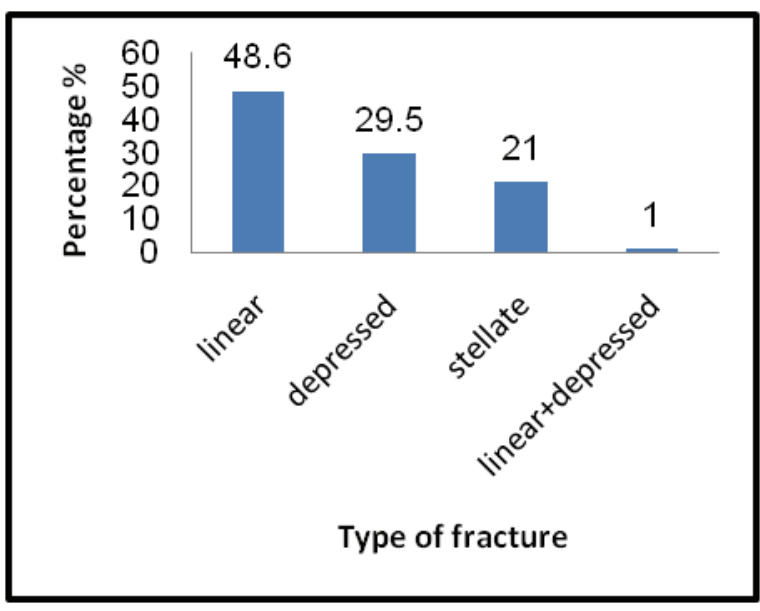

Figure 1: Frequency of fracture types.

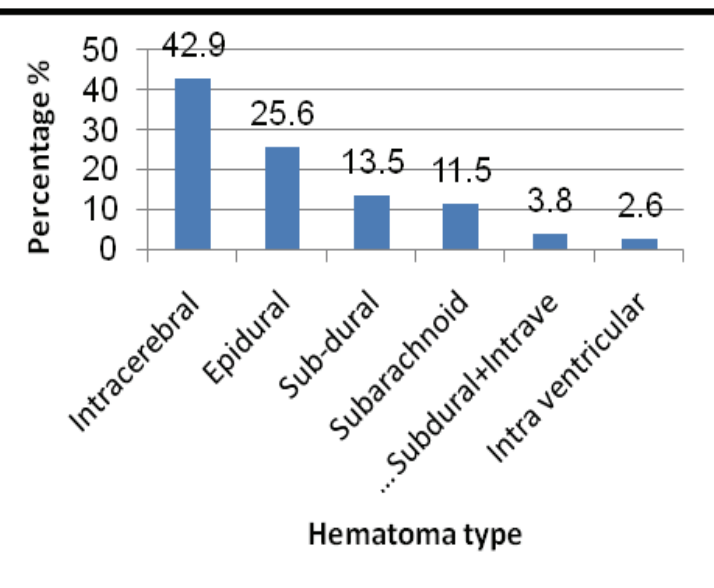

Figure 2: Frequency of hematoma types. 
Regarding the site of fractures, about a quarter $(23.8 \%)$ of fractures were located in the temporal region and other regions such as the base of the skull, frontal, parietal and occipital constitutes 19\%, $17.1 \%, \quad 14.3 \%$ and $12.4 \%$ respectively. Details are shown in Figure 3. Regarding other types of injuries observed by CT scan among cases were as following; soft tissue swelling (31.6\%), midline shift $(15.8 \%)$, contusion $(15.8 \%)$, pneumocephalus $(3.8 \%)$, hydrocephalus $(1.5 \%)$ and other combined injuries between above-mentioned injuries constitutes (31.8\%) (Figure 4).

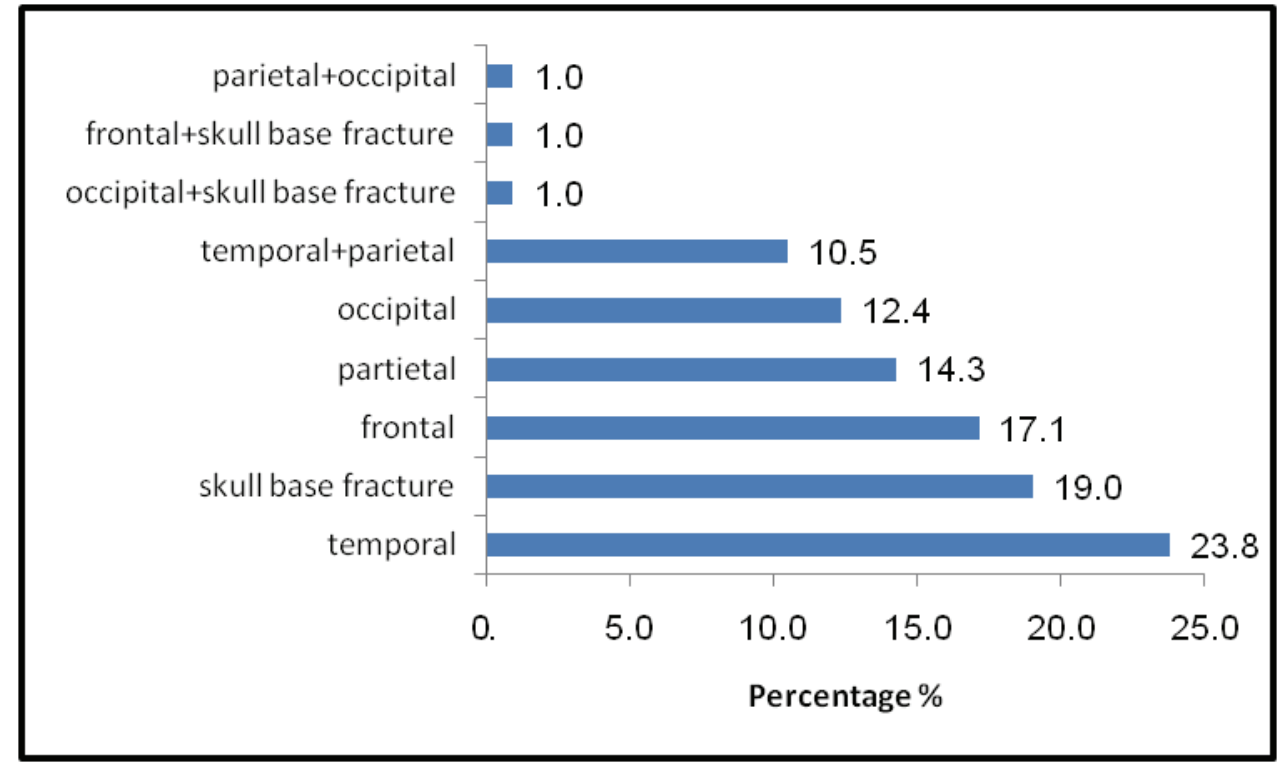

Figure 3: Site of fractures among the study sample.

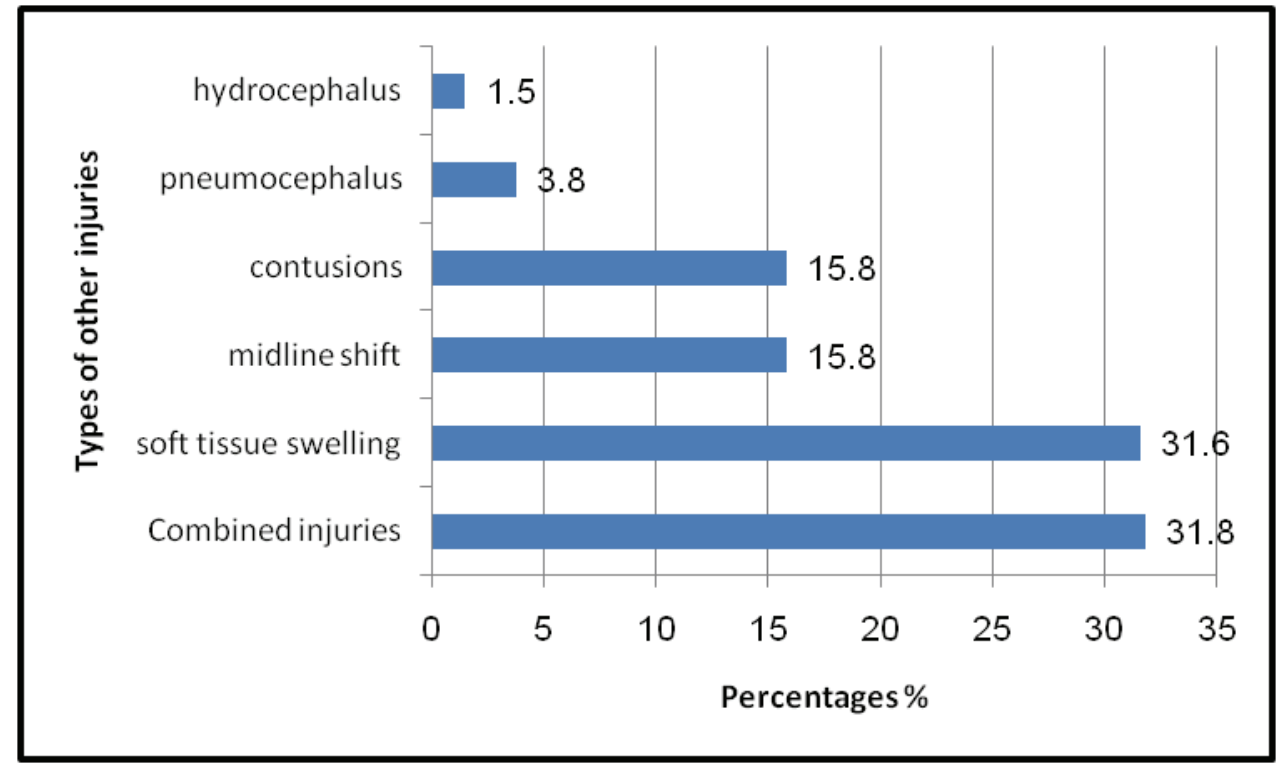

Figure 4: Frequency of other types of injury among the study sample. 
The current study showed that among the total 69 cases of brain edema observed by CT scan; $55 \%$ was local brain edema and $45 \%$ was diffuse brain edema (Figure 5). Among only 13 cases of incidental finding $(46.2 \%)$ was ischemia and $(23.1 \%)$ was arachnoids cyst (Figure 6). Regarding the association of the cause of injury with gender and age of the study sample, this study revealed a statistically significant association. The prevalence of RTA was significantly higher $(74.5 \%)$ in males than in females $(33.3 \%), \quad P<0.001$. The prevalence of fall and assault injury was higher among females (42.2\% and $24.4 \%$, respectively), $P<0.001$ than males $(13.3 \%$ and $12.1 \%$, respectively), $P=0.048$. RTA was relatively increasing with advancing age, $P<0.001$. The fall was significantly highest in the age group $0-10$ years $(85.1 \%)$ followed by the age group of $11-20$ years $(33.3 \%), P<0.001$. Assault injury was significantly highest in the age group 11-20, $P<0.001$ (Table 2).

Table 2: Relation between causes of injuries in regards to sex and age of the study sample.

\begin{tabular}{|c|c|c|c|c|c|c|c|c|}
\hline \multirow{3}{*}{ Variables } & \multicolumn{6}{|c|}{ Cause of injury } & \multirow{2}{*}{\multicolumn{2}{|c|}{ Total }} \\
\hline & \multicolumn{2}{|c|}{ RTA } & \multicolumn{2}{|c|}{ Fall } & \multicolumn{2}{|c|}{ Assault injury } & & \\
\hline & No. & $\%$ & No. & $\%$ & No. & $\%$ & No. & $\%$ \\
\hline Male & 123 & 74.5 & 22 & 13.3 & 20 & 12.1 & 165 & 100.0 \\
\hline Female & 15 & 33.3 & 19 & 42.2 & 11 & 24.4 & 45 & 100.0 \\
\hline Total & 138 & 65.7 & 41 & 19.5 & 31 & 14.8 & 210 & 100.0 \\
\hline$P$ value & \multicolumn{2}{|c|}{$<0.001$} & \multicolumn{2}{|c|}{$<0.001$} & \multicolumn{2}{|c|}{0.048} & & \\
\hline \multicolumn{9}{|l|}{ Age } \\
\hline $0-10$ & 1 & 3.7 & 23 & 85.2 & 3 & 11.1 & 27 & 100.0 \\
\hline $11-20$ & 10 & 41.7 & 8 & 33.3 & 6 & 25.5 & 24 & 100.0 \\
\hline $21-30$ & 51 & 77.3 & 4 & 6.1 & 11 & 16.7 & 68 & 100.0 \\
\hline $31-40$ & 38 & 74.5 & 4 & 7.8 & 9 & 17.6 & 51 & 100.0 \\
\hline $41-50$ & 21 & 91.3 & 0 & 0.0 & 2 & 8.7 & 23 & 100.0 \\
\hline $51-60$ & 8 & 88.9 & 1 & 11.1 & 0 & 0.0 & 10 & 100.0 \\
\hline$>60$ & 9 & 90.0 & 1 & 10.0 & 0 & 0.0 & 10 & 100.0 \\
\hline Total & 138 & 65.7 & 41 & 19.5 & 31 & 14.8 & 210 & 100.0 \\
\hline$P$ value & \multicolumn{2}{|c|}{$<0.001^{*}$} & \multicolumn{2}{|c|}{$<0.001^{*}$} & \multicolumn{2}{|c|}{$<0.001^{*}$} & & \\
\hline
\end{tabular}

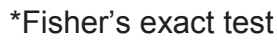

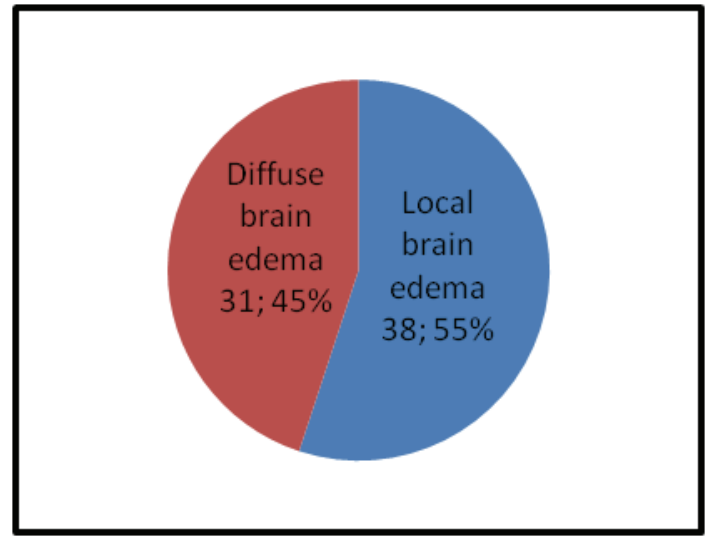

Figure 5: Frequency of brain edema.

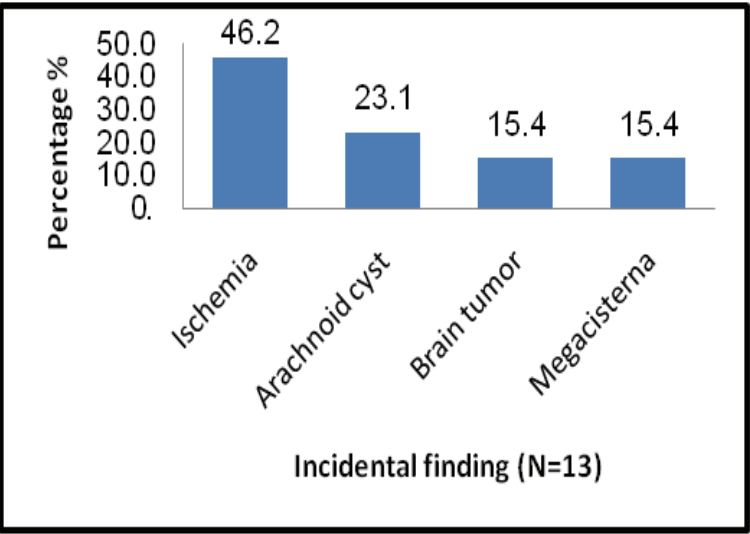

Figure 6: Frequency of incidental finding. 
With regard to the distribution of fracture type with fracture location, linear fracture was mostly located in the skull base $(27.5 \%)$ followed by frontal, temporal and parietal region $(21.6 \%, 25.5$ and $11.8 \%$, respectively), while depressed fracture was highest in temporal region $(25.8 \%)$ and followed by frontal (19.4\%), parietal $(12.9 \%)$, occipital $(19.4 \%)$, and (temporal + parietal) region $(19.4 \%)$. The highest rate of stellate fracture was in skull base region $(27.3 \%)$ and followed by parietal $(22.7 \%)$, while only one case $(100.0 \%)$ of linear depressed fracture was observed in frontal region (Table 3). The intracerebral hematoma was highest in the frontal region
(40.6\%) followed by temporal (18.8\%) and occipital (12.5\%). The subdural hematoma was highest in the temporal region $(50.0 \%)$ followed by parietal $(28.6 \%)$. The epidural hematoma was highest in the temporal + parietal region. Subarachnoid hematoma was observed to be associated with skull base fracture $(91.7 \%)$ and temporal region fracture $(8.3 \%)$, while intraventricular hematoma observed in association with skull base fracture $(100.0 \%)$ and intraventricular + subdural hematoma observed in skull base and (frontal + skull base) $(80 \%$ and $20 \%$, respectively) as shown in Table 4.

Table 3: Distribution of fracture type and location of fracture in the study sample.

\begin{tabular}{|c|c|c|c|c|c|c|c|c|c|c|}
\hline \multirow[b]{2}{*}{$\begin{array}{c}\text { Fracture } \\
\text { type }\end{array}$} & \multirow[b]{2}{*}{$\begin{array}{c}\text { Frontal } \\
\text { No. } \\
(\%)\end{array}$} & \multirow[b]{2}{*}{$\begin{array}{c}\text { Temporal } \\
\text { No. (\%) }\end{array}$} & \multirow[b]{2}{*}{$\begin{array}{l}\text { Parietal } \\
\text { No. (\%) }\end{array}$} & \multicolumn{3}{|c|}{ Fracture location } & \multirow[b]{2}{*}{$\begin{array}{c}\text { Occipital } \\
\text { + skull } \\
\text { base } \\
\text { No. }(\%) \\
\end{array}$} & \multirow[b]{2}{*}{$\begin{array}{c}\text { Frontal+ } \\
\text { skull } \\
\text { base } \\
\text { No. (\%) }\end{array}$} & \multirow[b]{2}{*}{$\begin{array}{c}\text { Parietal+ } \\
\text { occipital } \\
\text { No. (\%) }\end{array}$} & \multirow[b]{2}{*}{$\begin{array}{l}\text { Total } \\
\text { No. (\%) }\end{array}$} \\
\hline & & & & $\begin{array}{l}\text { Occipital } \\
\text { No. (\%) }\end{array}$ & $\begin{array}{c}\text { Skull } \\
\text { base } \\
\text { No. (\%) }\end{array}$ & $\begin{array}{c}\text { Temporal + } \\
\text { parietal } \\
\text { No. (\%) }\end{array}$ & & & & \\
\hline Linear & $\begin{array}{c}11 \\
(21.6)\end{array}$ & $13(25.5)$ & $6(11.8)$ & $\begin{array}{c}3 \\
(5.9)\end{array}$ & $\begin{array}{c}14 \\
(27.5)\end{array}$ & $\begin{array}{c}3 \\
(5.9)\end{array}$ & $\begin{array}{c}0 \\
(0.0)\end{array}$ & $\begin{array}{c}1 \\
(2.0)\end{array}$ & $\begin{array}{c}0 \\
(0.0\end{array}$ & $\begin{array}{c}51 \\
(100.0)\end{array}$ \\
\hline Depressed & $\begin{array}{c}6 \\
(19.4)\end{array}$ & $\begin{array}{c}8 \\
(25.8)\end{array}$ & $\begin{array}{c}4 \\
(12.9)\end{array}$ & $\begin{array}{c}6 \\
(19.4)\end{array}$ & $\begin{array}{c}0 \\
(0.0)\end{array}$ & $\begin{array}{c}6 \\
(19.4)\end{array}$ & $\begin{array}{c}1 \\
(3.2)\end{array}$ & $\begin{array}{c}0 \\
(0.0)\end{array}$ & $\begin{array}{c}0 \\
(0.0)\end{array}$ & $\begin{array}{c}31 \\
(100.0)\end{array}$ \\
\hline Stellate & $\begin{array}{c}0 \\
(0.0)\end{array}$ & $\begin{array}{c}4 \\
(18.2)\end{array}$ & $\begin{array}{c}5 \\
(22.7)\end{array}$ & $\begin{array}{c}4 \\
(18.2)\end{array}$ & $\begin{array}{c}6 \\
(27.3)\end{array}$ & $\begin{array}{c}2 \\
(9.1)\end{array}$ & $\begin{array}{c}0 \\
(0.0)\end{array}$ & $\begin{array}{c}0 \\
(0.0)\end{array}$ & $\begin{array}{c}1 \\
(4.5)\end{array}$ & $\begin{array}{c}22 \\
(100.0)\end{array}$ \\
\hline $\begin{array}{l}\text { Linear+ } \\
\text { depressed }\end{array}$ & $1(100.0)$ & $\begin{array}{c}0 \\
(0.0)\end{array}$ & $\begin{array}{c}0 \\
(0.0)\end{array}$ & $\begin{array}{c}0 \\
(0.0)\end{array}$ & $\begin{array}{c}0 \\
(0.0)\end{array}$ & $\begin{array}{c}0 \\
(0.0)\end{array}$ & $\begin{array}{c}0 \\
(0.0)\end{array}$ & $\begin{array}{c}0 \\
(0.0)\end{array}$ & $\begin{array}{c}0 \\
(0.0)\end{array}$ & $\begin{array}{c}1 \\
(100.0)\end{array}$ \\
\hline Total & $\begin{array}{c}18 \\
(17.1)\end{array}$ & $\begin{array}{c}25 \\
(23.8)\end{array}$ & $\begin{array}{c}15 \\
(14.3)\end{array}$ & $\begin{array}{c}13 \\
(12.4)\end{array}$ & $\begin{array}{c}20 \\
(19.0)\end{array}$ & $\begin{array}{c}11 \\
(10.5)\end{array}$ & $\begin{array}{c}1 \\
(1.0)\end{array}$ & $\begin{array}{c}1 \\
(1.0)\end{array}$ & $\begin{array}{c}1 \\
(1.0)\end{array}$ & $\begin{array}{c}105 \\
(100.0)\end{array}$ \\
\hline
\end{tabular}

Chi-square/Fisher's exact test not applicable

Table 4: Distribution of hematoma type and location of fracture in the study sample.

\begin{tabular}{|c|c|c|c|c|c|c|c|c|c|c|}
\hline \multirow[b]{2}{*}{ Hematoma type } & \multicolumn{9}{|c|}{ Fracture location } & \multirow[b]{2}{*}{ Total } \\
\hline & Frontal & Temporal & Parietal & Occipital & $\begin{array}{l}\text { Skull base } \\
\text { fracture }\end{array}$ & $\begin{array}{l}\text { Temporal } \\
\text { + parietal }\end{array}$ & $\begin{array}{l}\text { Occipital } \\
\text { Skull base } \\
\text { fracture }\end{array}$ & $\begin{array}{l}\text { Frontal+ skull } \\
\text { base fracture }\end{array}$ & $\begin{array}{l}\text { Parietal+ } \\
\text { occipital }\end{array}$ & \\
\hline Intracerebral & $\begin{array}{c}13 \\
(40.6)\end{array}$ & $\begin{array}{c}6 \\
(18.8)\end{array}$ & $\begin{array}{c}3 \\
(9.4)\end{array}$ & $\begin{array}{c}4 \\
(12.5)\end{array}$ & $\begin{array}{c}2 \\
(6.3)\end{array}$ & $\begin{array}{c}2 \\
(6.3)\end{array}$ & $\begin{array}{c}1 \\
(3.1)\end{array}$ & $\begin{array}{c}0 \\
(0.0)\end{array}$ & $\begin{array}{c}1 \\
(3.1)\end{array}$ & $\begin{array}{c}32 \\
(100.0)\end{array}$ \\
\hline Subdural & $\begin{array}{c}1 \\
(7.1)\end{array}$ & $\begin{array}{c}7 \\
(50.0)\end{array}$ & $\begin{array}{c}4 \\
(28.6)\end{array}$ & $\begin{array}{c}1 \\
(7.1)\end{array}$ & $\begin{array}{c}0 \\
(0.0)\end{array}$ & $\begin{array}{c}1 \\
(7.1)\end{array}$ & $\begin{array}{c}0 \\
(0.0)\end{array}$ & $\begin{array}{c}0 \\
(0.0)\end{array}$ & $\begin{array}{c}0 \\
(0.0)\end{array}$ & $\begin{array}{c}14 \\
(100.0)\end{array}$ \\
\hline Epidural & $\begin{array}{c}2 \\
(6.9)\end{array}$ & $\begin{array}{c}7 \\
(24.1)\end{array}$ & $\begin{array}{c}6 \\
(20.7)\end{array}$ & $\begin{array}{c}6 \\
(20.7)\end{array}$ & $\begin{array}{c}0 \\
(0.0)\end{array}$ & $\begin{array}{c}8 \\
(27.6)\end{array}$ & $\begin{array}{c}0 \\
(0.0)\end{array}$ & $\begin{array}{c}0 \\
(0.0)\end{array}$ & $\begin{array}{c}0 \\
(0.0)\end{array}$ & $\begin{array}{c}29 \\
(100.0)\end{array}$ \\
\hline Subarachnoid & $\begin{array}{c}0 \\
(0.0)\end{array}$ & $\begin{array}{c}1 \\
(8.3)\end{array}$ & $\begin{array}{c}0 \\
(0.0)\end{array}$ & $\begin{array}{c}0 \\
(0.0)\end{array}$ & $\begin{array}{c}11 \\
(91.7)\end{array}$ & $\begin{array}{c}0 \\
(0.0)\end{array}$ & $\begin{array}{c}0 \\
(0.0)\end{array}$ & $\begin{array}{c}0 \\
(0.0)\end{array}$ & $\begin{array}{c}0 \\
(0.0)\end{array}$ & $\begin{array}{c}12 \\
(100.0)\end{array}$ \\
\hline $\begin{array}{l}\text { Intra } \\
\text { ventricular }\end{array}$ & $\begin{array}{c}0 \\
(0.0)\end{array}$ & $\begin{array}{c}0 \\
(0.0)\end{array}$ & $\begin{array}{c}0 \\
(0.0)\end{array}$ & $\begin{array}{c}0 \\
(0.0)\end{array}$ & $\begin{array}{c}3 \\
(100.0)\end{array}$ & $\begin{array}{c}0 \\
(0.0)\end{array}$ & $\begin{array}{c}0 \\
(0.0)\end{array}$ & $\begin{array}{c}0 \\
(0.0)\end{array}$ & $\begin{array}{c}0 \\
(0.0)\end{array}$ & $\begin{array}{c}3 \\
(100.0)\end{array}$ \\
\hline $\begin{array}{l}\text { Subdural+ } \\
\text { intraventricular }\end{array}$ & $\begin{array}{c}0 \\
(0.0)\end{array}$ & $\begin{array}{c}0 \\
(0.0)\end{array}$ & $\begin{array}{c}0 \\
(0.0)\end{array}$ & $\begin{array}{c}0 \\
(0.0)\end{array}$ & $\begin{array}{c}4 \\
(80.0)\end{array}$ & $\begin{array}{c}0 \\
(0.0)\end{array}$ & $\begin{array}{c}0 \\
(0.0)\end{array}$ & $\begin{array}{c}1 \\
(20.0)\end{array}$ & $\begin{array}{c}0 \\
(0.0)\end{array}$ & $\begin{array}{c}5 \\
(100.0)\end{array}$ \\
\hline Total & $\begin{array}{c}16 \\
(16.8)\end{array}$ & $\begin{array}{c}21 \\
(22.1)\end{array}$ & $\begin{array}{c}13 \\
(13.7)\end{array}$ & $\begin{array}{c}11 \\
(11.6)\end{array}$ & $\begin{array}{c}20 \\
(21.1)\end{array}$ & $\begin{array}{c}11 \\
(11.6)\end{array}$ & $\begin{array}{c}1 \\
(1.1)\end{array}$ & $\begin{array}{c}1 \\
(1.1)\end{array}$ & $\begin{array}{c}1 \\
(1.1)\end{array}$ & $\begin{array}{c}95 \\
(100.0)\end{array}$ \\
\hline
\end{tabular}




\section{Discussion}

The results from this study showed a significantly higher frequency of traumatic brain injury in males $(74.5 \%)$ than in females (21.4\%). The predilection for young males as seen in this study had been previously reported by several studies that reported the ratio of head injuries in male to female to be 3 to $1 .^{8}$ The high predilection of young males is not unexpected as they constitute an active group that is more likely to be involved in accidents. $^{9}$ The majority of our patients were found to be in the second -third decade of life mean age was 29.23 (simply because this age group is the most active and productive group and are more likely to be exposed to both occupational and social risks. ${ }^{10}$ The finding of RTA as a main cause of head injury $(65.7 \%)$, agrees with other reports on head injury in developing countries in which the incidence of traumatic brain injury is increasing as traffic increases (high number of vehicles, poor roads, ignorance of traffic rules and regulations), besides other confounding factors such as industrialization, ballistic trauma and falls. ${ }^{11,12}$ A percentage very close to that of a report by Akanji et al. who found falls as the cause of head injury in $16.8 \%$ of their participants ${ }^{13}$; falls constituted $19.5 \%$ of the cases in this study; of these cases of fall, $85.2 \%$ were in the first decade of life. This high incidence in pediatric age may be attributed to their involvement in high risk activities and adventures at home and in schools. Definite indications of CT scanning after head trauma includes a deteriorating clinical course, focalneurologic deficit, abnormal mental status, evidence of skull fracture and the presence of coagulopathy. Also, until additional evidence is available, loss of consciousness and persistent vomiting (more than three times) should be taken into consideration. ${ }^{14}$ In this study, most of the indications were a change of consciousness and vomiting. On the other hand, several studies have reported vomiting as a post-traumatic symptom, which predicts abnormality related to the trauma in brain CT scan, but Viola et al. said that vomiting was insignificant. ${ }^{15}$ This study showed that intracranial hematomas seen in less than half of patients (95 out of 210 ), and the most common intracranial hematoma type was intracerebral $(42.9 \%)$ followed by epidural $(25.6 \%)$, subdural (13.5\%), subarachnoid (11.5\%) and intraventricular (2.6\%). Ashley et al. similarly found intracerebral hematoma as the most intracranial bleed, ${ }^{9}$ whereas Ogunsheyinde et al. found subdural hematoma as the most common bleed. ${ }^{16}$ Shiomi and Echigo even had epidural hematoma as the most intracranial bleed in their study. ${ }^{4}$ Among the wide spectrum of injuries included in traumatic brain injury, subarachnoid hemorrhage is one of the leading causes of morbidity and functional impairment. The incidence of traumatic SAH varies from $26 \%$ to $53 \%$ in patients with traumatic brain injury, ${ }^{17}$ in the present study the incidence was $11.5 \%$. Although traumatic intraventricular hemorrhage is rare but can be associated with severe morbidity and mortality and its presence indicates severe head trauma, ${ }^{18}$ it was found as an isolated type of hematoma in $2.6 \%$ and $3.8 \%$ in combination with a subdural hematoma. The commonest abnormal finding in this study was fracture (50\%, 105 out of 210$)$, either occurring with other associated intracranial lesions or independently; the literature shows an incidence of $2 \%-42 \%$ of skull fractures in acute head trauma. ${ }^{19}$ The most common type of fracture was linear $(51 \%)$, as it is estimated that $75 \%$ of all skull fractures are linear. ${ }^{20}$ The commonest site involved is temporal bone $(23.8 \%)$, skull base $(19 \%)$ and frontal bone $(17.1 \%)$. The skull base was the site of predilection for linear and stellate type fracture $(27.5 \%$ and $27.3 \%$, respectively) while depressed type was most common at temporal region (25.8\%) followed by frontal, occipital and temporo-parietal region (19.4\% for each one of them). Obajimi et al. in Ghana recorded $100 \%$ association of extradural 
and intracerebral hematoma with skull fractures. ${ }^{21}$ In the present study intracerebral hematomas are more associated with skull fracture (32\%) than epidural hematoma (29\%). Cortical contusions were found in $(15.8 \%)$ of cases. Ohaegbulam et al. in Enugu observed cerebral contusion to be the most common type of intracerebral hematoma. ${ }^{22}$ In our study, the analysis done only on first initial CT scans and in many instances cortical contusions will not be apparent on initial scan and will appear on the follow up scan that is why the percentage of cortical contusion might be much higher. Cranial CT scan based previous studies reported the prevalence of $1 \%$ to $19 \%$ of incidental findings in post-traumatic head injury patients. ${ }^{23}$ Incidental brain findings in the current study were seen in $(6.9 \%)$ of cases (13 out of 210 ), among these $(46.2 \%)$ were brain ischemic changes, $23.1 \%$ were arachnoid cyst, thoughischaemic brain changes were the main incidental finding in our study, the small percentage $(6.9 \%)$ is the clue to the relatively young age group involved in our study.

\section{Conclusion}

This study yielded the advantages of CT scan in the evaluation of patients with acute head injury, including its sensitivity for detecting a mass effect, ventricular size and configuration, bone injuries and various types of acute intracranial hemorrhage.

\section{Competing interests}

The author declares no competing interests.

\section{References}

1. Corando VG, Xu L, Basavaraju SV, McGuire LC, Wald NM, Faul MD, et al. Surveillance for traumatic brain injury-related deaths: United States,1997-2007. Atlanta: US Department of Health and Human Services, Centers for Disease and Prevention; 2011.

2. Edwards $P$, Arango M, Balica L, Cottingham R, El-Sayed $H$, Farrell $B$, et al. Final results of MRC $\mathrm{CRASH}$, a randomized placebo controlled trial of intravenous corticosteroid in adults with head injury outcomes at 6 months. Lancet 2005; 365:1957-9.

3. Hukkelhuven CW, Stegerberg CW, Rampen AJ, Farace E, Habbema JD, Marshall LF. Patient age and outcome following severe traumatic brain injury: An analysis of 5600 patients. J Neurosurg 2003; 99:666-73.

4. Shiomi N, Echigo T. A guide to initial management of minor head injury. No Shinkei Geka 2004; 32:465-70.

5. Murray CJ, Lopez AD, editors, Global Burden of Disease: A Comprehensive Assessment of Mortality and Disability from Diseases, Injuries and Risk Factors in 1990 and Projected 2020. Boston: Harvard University Press; 1996.

6. Commissioned by the National Institute of Health and Clinical Excellence Head injury: triage, assessment, investigation and early management of head injury in infants, children and adults. United Kingdom: National Collaborating Centre for Acute Care; 2007.

7. Shivanand G, Atin K, Arun KG. Imaging of head trauma. In: Niranjan K, Veena C, Arun KG, editors. Diagnostic Radiology: Including Head and Neck Imaging. $3^{\text {rd }}$ ed. New Delhi, India: Jaypee Brothers Medical Publishers Ltd; 2010.

8. Fakharian E, Fazel MR, Tabesh H, Nabavi Z. Incidence of mild head injury, management, and expenses in Kashan,2003-2004. Feyz J Kashan Uni Med Sci 2007; 11(3):21-6.

9. Ashaleye CM, Famurewa OC, Komolafe MA, Amusa YB. The pattern of computerized tomographic findings in moderate and severe head injuries in Ile-Ife, Nigeria. West Afr J Radiol 2005; 12:8-3.

10. Saadat $S$, Yousefifard $M$, Asady $H$, Jafari AM, Fayaz M, Hosseini M. The most important causes of death in Iranian population; A retrospective cohort study. Emerg (Tahran) 2015;3(1):16-21.

11. Emejulu JK, Ekweogwu C, Nottidge T. The burden of motorcycle-related Neurotrauma in South-East Nigeria. J Clin Med Res 2009; 1:137.

12. Mebrahtu-Ghebrehiwet M, Quan LH, Andebirhan T.The profile of CT scan findings in acute head trauma in Orotta Hospital, Asmara, Eriteria. J Eriterean Med Assoc 2009; 4(1):5-8.

13. Akanji AO, Akinola RA, Balogun BO, Akano AO, Atalabi OM, Akinkunmi MA, et al. Computed tomography scan and head injury. The experience in a tertiary hospital in Nigeria. A cross sectional study. Med Pract Rev 2015; 6 (2):1-15.

14. Gordon KE. Pediatric minor traumatic brain injury. Seminars in Pediatric Neurology 2006; 13(4):243-55.

15. Viola L, Zotta D, Martino V, Barbato R, Schisano Minor head injuries: One-year experience according to the new Italian guideline. Acta Neurochir Wien 2000; 142:1281-5. 
16. Ogunsheyinde AO, Obajimi MO, Ogundare SM. Radiological evaluation of head trauma by computed tomography in Ibadan, Nigeria, West Afr J Med 1999; 18:33-8.

17. Zacko JC, Haris L, Bullock MR. Surgical management of traumatic brain injury. In: Winn HR. Youmans Neurological Surgery. $6^{\text {th }}$ ed. New York: Saunders; 2011. P. 3428.

18. Lee B, Newberg A. Neuroimaging in traumatic brain imaging. NeuroRx 2005; 2(2):372-83.

19. Zimmerman RA, Gibby WA, Carmody RF Neuroimaging, clinical and physical principles. New York: Springer Verley; 2000.

20. Atabaki SM. Paediatric head injury. Paediatric Rev 2007; 28:215-24.

21. Obajimi MO, Jumah KB, Brakohuapa WO Iddrisu W. Computed tomography features of head injury in Ghanaian children. Niger J Surg Res 2002; 4:84-8.

22. Ohaegbulam SC, Mezue WC, Ndubuisi CA, Erechukwu UA, Ani CO. Cranial computed tomography scan findings in head trauma patients in Enugu, Nigeria. Surg Neurol Int 2011; 2:182.

23. Thompson RJ, Wojcik SM, Grant WD, Ko PY. Incidental findings on CT scans in the emergency department. Emerg Med Int 2011; 2011:1-4. 